\title{
New perspectives in the psychotherapy of psychoses at onset: evidence, effectiveness, flexibility, and fidelity
}

\author{
Nuove prospettive per la psicoterapia dell'esordio psicotico: \\ fra evidenze, efficacia nella pratica, flessibilità e fidelity
}

\author{
M. Ruggeri*, Guest Editor and M. Tansella, Editor
}

Currently, various attempts are underway to implement specialised treatment services for first-episode psychosis, with the aim to offer evidence-based care that optimises outcomes and minimises deterioration, based on mounting evidence from randomised controlled studies showing that specialised early psychosis services are more effective than treatment as usual. These programmes are being conducted either in stand-alone specific services, or by dedicated teams working within the framework of existing community mental health services. Clinical practice guidelines (Addington, 2009) make a number of recommendations and list several crucial service components that should be included in treatment services, such as cognitive-behavioural strategies, early family psychoeducation, assertive outreach, and supported employment.

The general consensus on the continuing researchpractice gap has prompted greater efforts to disseminate and implement evidence-based practices in community-based settings, by highlighting the epidemiology of evidence-based health intervention data and by adapting and putting these interventions into practice over time. To accomplish this goal, researchers find themselves grappling with a number of key issues, including how to best translate intervention programmes to encourage uptake and implementation in ways that preserve the scientifically validated components of evidence-based practices; and how to integrate the efforts of the various stakeholders in settings over which researchers have little control. It is therefore becoming ever more crucial to develop ways to sustain intervention programmes aimed to maintain the integrity of evidence-based treatments in real-world settings after the completion of the research phase.

*Address for correspondence: Professor Mirella Ruggeri, Department of Public Health and Community Medicine, Section of Psychiatry and Clinical Psychology, Ospedale Policlinico "G.B. Rossi", Piazzale L.A. Scuro 10, 37134 Verona, Italy.

(Email: mirella.ruggeri@univr.it)
Early psychosis intervention programmes require accurate performance measures to determine what progress has been made towards specifically defined organisational objectives. These measures should comprehensively evaluate: accessibility, acceptability, appropriateness, continuity, therapist's competence, fidelity to the theoretical models, effectiveness, efficiency, and safety.

The main questions representing the challenges of implementing programmes in routine mental health care over the next few years are as follows:

(a) Which domains are more relevant to be treated in routine clinical services to obtain optimal patient and families outcomes, and which are more susceptible to effective treatment?

(b) Which 'treatment dosages' should be administered and what degree of flexibility is required to meet the needs of patients and families?

(c) How might the use of valid and reliable measures be optimised to ensure that new programmes adhere to protocols or to programme models shown to be effective?

(d) What are the limitations of fidelity in relation to clinical variability?

Evidence from outcome studies show that individuals with severe mental illness can live full, meaningful, and productive lives and this therefore requires a focus on the importance of promoting recoveryoriented services by policy makers. A key challenge in implementing these kinds of services is that of effectively translating the values or principles of recovery into clear-cut service delivery strategies.

Recovery-oriented domains of clinical practice include a focus on life goals, consumer involvement, diversity in treatment options, emphasis upon consumer choice, and individually tailored services. For example, in the early treatment of psychosis, not only should patients' prototypical symptoms of psychosis, such as positive and negative symptoms, receive treatment, but also their affective responses and shame-based 
appraisals and emotions. In fact, traumatic patient responses to psychosis appear to be common and can cause great distress, increased risk of suicidality, comorbidity including substance misuse, and poor engagement with treatment and services. Indeed, an array of mediating and moderating variables, such as cognitive appraisal, coping style, and shameproneness can influence the degree to which the experience of psychosis influences Post Traumatic Stress Disorder (PTSD)-type symptoms (Jackson et al. 2009). These mediating and moderating variables will ultimately influence the phenomenology, course, and treatment of these symptoms.

The Editorial by Jackson et al. published in the current issue of Epidemiology and Psychiatric Sciences provides an enlightening example of the complexities involved in the treatment of psychosis, and on the psychotherapeutical strategies which show promising results, such as cognitive re-structuring of, and psycho-education for trauma-related symptoms; therapies based on an emotional processing paradigm aimed at helping patients and carers in the immediate aftermath of a first episode of psychosis to integrate and emotionally process their experience of the patient's symptoms and their management; and application of the most recent developments in this field such as compassion focussed therapy. It is not yet clear, however, which intervention components are best suited for which symptoms (Morrison \& Barratt, 2010). Moreover, the situation is further complicated by the variability with which PTSD symptoms are defined, measured, and used as outcome measures in these studies (Bebbington, 2009; Lasalvia \& Tansella, 2009).

Moreover, clinical variability (as compared with highly homogeneous research samples) represents the typical situation in early psychosis in routine settings, and therefore poses difficult challenges to the implementation of these treatments on a larger scale. In this light, the model of triaged family intervention proposed by Onwumere et al. in the second Editorial of this issue of Epidemiology and Psychiatric Sciences is of utmost relevance. The authors underscore that, based on their clinical observations, not all early psychosis families actually require full family intervention, and that under certain circumstances, it may even be harmful. Given the range of issues reported, some early psychosis families may likely require only lowintensity intervention programmes. Conversely, intensive forms of intervention are probably most appropriate for families presenting both previous and ongoing severe relationship difficulties, instances of service users presenting persisting symptoms or frequent relapses, or when caregivers are experiencing complicated grief reactions (Onwumere et al. 2010).
The findings from empirical research on the psychotherapy of mental disorders suggest that therapist competence plays a key role in producing positive treatment outcomes. Yet, the extent to which these findings generalise to the complex environment of everyday clinical practice remains unclear. The relationships between therapist adherence to theoretical models (fidelity), therapist competence, training, and supervision; and clinical variability must be thoroughly investigated, as well as the best ways to assess these characteristics.

Treatment fidelity refers to the methodological strategies used to examine and enhance the reliability and validity of interventions (Alvarez-Jimenez et al. 2008), as it is necessary to maintain validity and to ensure a fair comparison between interventions. In the absence of fidelity evaluation, ineffective techniques may be implemented and disseminated at a high cost to the community and the individual, and disentangling specific from non-specific treatment factors may prove to be difficult. Conversely, if fidelity is not considered and non-significant results are found, it is not possible to discern whether the absence of treatment effect is due to an ineffective intervention or to poor treatment fidelity. As a result, potentially beneficial treatments for specific patient populations may be prematurely disregarded.

Several features of the research setting limit the generalisability of data obtained, and it currently seems much easier manualise therapies in research settings than in the real world (Kidd et al. 2010). Although the therapy manual is considered the main vehicle for transferring empirically supported psychotherapies into clinical practice, the actual value of generalising the requirement for treatment manual adherence is debatable. In fact, some evidence suggests that best outcomes are obtained by therapists who demonstrate flexibility by adapting their interventions to their individual clients' needs (Cohen et al. 2008).

Strict adherence to a highly structured manual could prove effective, on average, for clients presenting with clearly defined problems (e.g. major depression, panic disorder, social phobia), but less so for patients experiencing a more complex series of presenting problems, such as those often encountered in the framework of early psychoses. Thus, the issue of the degree to which psychotherapies must involve flexible modification and integration to be effective when applied in everyday clinical work, remains an open one. As emphasised by David Fowler and his collaborators in the third Editorial of this issue of Epidemiology and Psychiatric Sciences, a growing variety of measures are now available to assess therapist competence in CBT. Unfortunately, the lack of an agreed operational definition for the competence construct, as distinct from that of adherence, means 
that it is difficult to choose a measure for use in clinical training or supervision. In fact, current measures of therapist adherence continue to show a certain degree of confounding between the 'therapist adherence' and 'therapist competence' constructs.

Establishing treatment fidelity is essential in determining what aspects of the intervention are being implemented. Promising evidence has been gathered on the possibility of implementing evidence-based practices with moderate-to-high fidelity in mental health centres (McHugo et al. 2007; Petrakis et al.

Numerose sono le iniziative in corso mirate a ottenere, mediante l'uso di trattamenti specifici, il migliore esito possibile per la psicosi all'esordio e prevenire il deterioramento e la disabilità, basandosi sulle indicazioni che provengono dagli studi randomizzati controllati che dimostrano che interventi specifici per l'esordio psicotico sono più efficaci dei trattamenti routinari. Questi programmi vengono attualmente condotti in Centri a questo specificatamente dedicati ('stand alone' specific services) oppure nell'ambito di team che operano nei Servizi di Salute Mentale esistenti sul territorio. Le linee guida cliniche elencano una serie di interventi cruciali che dovrebbero essere forniti in tali Servizi, quali ad esempio la psicoterapia ad orientamento cognitivo-comportamentale (CBT), l'intervento di psicoeducazione con le famiglie, l'assertive outreach e un supporto per lo svolgimento dell'attività lavorativa (Addington, 2009).

La discrepanza fra pratica clinica ed evidenze fornite dalla ricerca è un dato ben noto e rende particolarmente cruciale l'adattamento e la sperimentazione di tali pratiche nei servizi 'del mondo reale'. Per raggiungere questo obiettivi, è necessario tradurre questi interventi nella pratica ed implementarli in modo tale da preservarne le componenti che maggiormente contribuiscono alla loro efficacia, traendo il massimo profitto dal contributo di tutti gli 'attori' che intervengono nei contesti di routine, su cui inevitabilmente i ricercatori hanno poco controllo.

$E^{\prime}$ quindi particolarmente cruciale supportare i programmi di intervento ben oltre la dimostrazione teorica della loro efficacia, con iniziative mirate a diffondere tali trattamenti evidence-based nei setting del mondo reale e a mantenerne l'integrità.

I trattamenti per l'esordio psicotico richiedono l'utilizzo di misurazioni sistematiche che consentano di definire le varie tappe del raggiungimento di tali obiettivi, inclusivi di una valutazione dell'accessibilità, dell'appropriatezza, della continuità dell'intervento, della competenza dei terapeuti, della fedeltà ai modelli teorici di riferimento (fidelity), dell'efficacia nella pratica, dell'efficienza e della sicurezza dei programmi stessi.
2010); the critical time period for implementation seems the first year, after which few gains are made, although fidelity to evidence-based practice might be sustained for another year. If a fair balance between methodological rigour and flexibility will become a standard, research on treatment fidelity can contribute to a greater extent to our understanding of the mechanisms of treatments, and to increase our knowledge on how to integrate their construct, and identify the components that are related to the most effective therapeutic change.

Le sfide principali che al riguardo debbono oggi essere affrontate sono le seguenti:

(a) identificare quali sono le componenti del quadro clinico dell'esordio psicotico che debbono essere trattate in maniera prioritaria al fine di ottimizzare l'esito per i pazienti e per i familiari e quali di esse sono maggiormente suscettibili di risposta ai trattamenti

(b) identificare qual è 'la dose' di tali interventi che deve essere somministrata, e con quale flessibilità, al fine di rispondere ai bisogni reali dei pazienti e delle loro famiglie

(c) identificare gli strumenti che possono essere utilizzati per favorire una maggiore adesione ai modelli di trattamento di provata efficacia

(d) identificare i limiti di una misurazione della fidelity in relazione alla variabilità di quadri clinici che si riscontra nella pratica

Poichè gli studi di esito hanno dimostrato che nei pazienti affetti da psicosi si può aspirare ad un buon recupero delle loro abilità sociali, un obiettivo prioritario è quello di promuovere l'attuazione di interventi che siano effettivamente 'recovery-oriented', e che questi principi vengano tradotti in chiare strategie di intervento. Effettuare trattamenti 'recovery-oriented' significa focalizzarsi sugli obiettivi di vita che il paziente si pone, sul suo coinvolgimento attivo, sul ventaglio delle opzioni di trattamento disponibili, sulle preferenze del paziente, su di un approccio individualizzato. Ad esempio, nel trattamento dell'esordio psicotico appare particolarmente importante non solo prendersi cura de sintomi chiave del disturbo, quali ad esempio $i$ sintomi positivi o negativi, ma anche prendersi cura della componente affettiva ad essi legata e di quei vissuti di vergogna che sono spesso una conseguenza della sintomatologia psicotica. La reazione traumatica alla psicosi è infatti frequente, è causa di notevole disagio psichico e contribuisce notevolmente ad aumentare il rischio suicidiario, la comorbidità con uso di sostanze, la scarsa adesione ai trattamenti. Questi 
sintomatologia, che molte rassomiglianze ha con il Disturbo Post-Traumatico da Stress (Jackson et al. 2009), pare essere mediata da una serie di variabili che possono influenzarne la fenomenologia, il decorso e la risposta ai trattamenti, quali l'elaborazione cognitiva dell'esperienza, lo stile di coping, la tendenza a provare vergogna.

L'Editoriale di Jackson et al. pubblicato in questo numero di EPS costituisce una dimostrazione esemplare della complessità del trattamento delle psicosi e fornisce una esaustiva panoramica delle strategie terapeutiche che possono essere efficaci al fine di rielaborare il trauma post-psicotico, quali ad esempio: la ristrutturazione cognitiva, la psicoeducazione per i sintomi traumatici, le tecniche che favoriscono una rielaborazione emotiva e possono aiutare il paziente ed i suoi familiari nel periodo immediatamente successivo all'esordio psicotico l'applicazione di nuovi approcci di recente sviluppo, quali la 'compassionate focussed therapy'. Va detto che le evidenze presenti in letteratura ancora non hanno chiarito quali interventi sono maggiormente idonei per i sintomi di tipo post traumatico nelle psicosi, e qual è la loro specificità (Morrison \& Barratt, 2010), anche a causa della grande variabilità con cui tali sintomi vengono definiti e misurati negli studi di esito (Bebbington, 2009; Lasalvia \& Tansella, 2009).

La variabilità delle manifestazioni cliniche e dei problemi ad esse connesse è la norma negli esordi psicotici che vengono trattati 'nei servizi del mondo reale', a fronte dell'omogeneità che viene deliberatamente ricercata nei campioni utilizzati negli studi sperimentali. In questa luce, il modello di 'triage' degli interventi familiari proposto da Onwumere et al. nel secondo Editoriale di EPS assume una rilevanza esemplificativa in quanto gli autori affermano che, sulla base delle loro osservazioni cliniche, non tutte le famiglie di pazienti all'esordio psicotico necessitano un ciclo completo di sedute di intervento familiare e che, in alcune circostanze, questo può addirittura essere dannoso. A seconda dei casi, famiglie di pazienti all'esordio psicotico possono richiedere solo programmi di trattamento a bassa intensità, mentre invece famiglie con problematiche relazionali pregresse e in atto, o pazienti affetti da sintomi persistenti e frequenti ricadute, oppure casi in cui i familiari reagiscono alla psicosi del congiunto con reazioni emotive di perdita e lutto possono richiedere un trattamento intensivo (Onwumere et al. 2010).

I dati tratti dalle ricerche più recenti sulla psicoterapia dei disturbi psichici indicano che la competenza del terapeuta gioca un ruolo chiave nel determinare il buon esito di un intervento. Tuttavia non è chiaro quanto questo sia generalizzabile nei contesti complessi Vtifici delle pratiche di routine. Il rapporto fra l'aderenza del terapeuta ai modelli teorici di riferimento, la sua competenza, la tipologia del training e della supervisione e infine la variabilità clinica deve ancora essere appieno compreso, così come debbono essere meglio individuati i metodi che consentono di misurare al meglio queste variabili.

Con il termine 'analisi della fidelity di un trattamento', si indicano le strategie metodologiche impiegate per esaminare il grado di aderenza di un intervento ai modelli teorici di riferimento, al fine di aumentare la sua riproducibilità e la sua validità, anche in relazione alla possibilità di effettuare confronti fra interventi diversi. (Alvarez-Jimenez et al. 2008). In assenza di una valutazione della fedeltà di un trattamento, tecniche inefficaci rischiano di essere implementate e diffuse sul territorio, con conseguenti sprechi di risorse, e al contempo può essere difficile distinguere l'effetto dei fattori specifici e di quelli aspecifici. Oppure, nel caso in cui le valutazioni di fidelity non vengano condotte, può non essere possibile comprendere se trattamenti che risultano inefficaci lo sono per mancanza reale di efficacia o per scarsa fidelity, il che può indurre a scartare prematuramente trattamenti potenzialmente efficaci.

I fattori che potenzialmente limitano la generalizzabilità dei dati ottenuti nei contesti di ricerca sono molteplici, ed è certamente più semplice standardizzare le psicoterapie nei contesti di ricerca che nel mondo reale (Kidd et al. 2010). Nonostante i Manuali Operativi siano considerati il veicolo principale per trasferire le evidenze ottenute in setting sperimentali nella pratica clinica, la reale validità della generalizzazione dei requisiti richiesti per una adesione completa al Manuale è cosa assai discussa. Vi sono evidenze che indicano che i migliori risultati in termini di esito vengono ottenuti da terapeuti che dimostrano una buona flessibilità nell'adattare i propri interventi ai bisogni degli utenti (Cohen et al. 2008). Una stretta aderenza a Manuali altamente strutturati pare dimostrarsi efficace per i pazienti che presentano problemi ben definiti (ad esempio, la Depressione Maggiore, il Disturbo da Attacchi di Panico, la Fobia Sociale), ma assai meno per coloro che sperimentano problematiche più complesse, come spesso accade all'esordio psicotico. Tuttavia, il grado con cui le psicoterapie debbono contemplare la possibilità di essere flessibili e prevedere varie tipologie di integrazione rispetto ai modelli sperimentali per essere veramente efficaci nella pratica clinica resta un quesito aperto.

Come messo in evidenza da David Fowler e dai suoi collaboratori nel terzo Editoriale di questo numero di $E P S$, un numero crescente di metodi di misurazione sono oggi disponibili per misurare la competenza dei terapeuti nell'ambito della CBT. Sfortunatamente, la mancanza di una definizione operativa e condivisa del costrutto di 'competenza del terapeuta' distinto 
da quello di 'aderenza' rende difficile individuare le misurazioni più appropriate da utilizzare nei training clinici e nei processi di supervisione. Di fatto le misure attualmente utilizzate mantengono un certo grado di confusione fra i due costrutti.

La conoscenza della fidelity di un trattamento è essenziale per determinare quali componenti di uno specifico intervento sono da implementare. Alcuni studi hanno prodotto dati promettenti sulla possibilità di implementare pratiche innovative nelle routine clinica dei centri di salute mentale con una buona, o addirittura elevata, fidelity (McHugo et al. 2007; Petrakis et al. 2010); il periodo utile per il processo di implementazione sembra essere il primo anno, dopo il quale pochi miglioramenti si ottengono, mentre una buona fidelity alle pratiche evidence-based può persistere per un altro anno.

Se nel prossimo futuro sarà possibile creare un buon bilanciamento fra il rigore metodologico e la flessibilità, gli studi sulla fidelity dei trattamenti potranno contribuire in maniera rilevante alla comprensione dei meccanismi che intervengono nell'ambito dei trattamenti stessi, all'aumento delle conoscenze su come i diversi costrutti che sono sottesi all'attuazione di un intervento complesso possono essere integrati fra loro, e all'identificazione delle componenti che sono maggiormente correlate al buon esito dei trattamenti.

\section{References}

Addington D (2009). Best practices: improving quality of care for patients with first-episode psychosis. Psychiatric Services 60, 1164-1166.

Alvarez-Jimenez M, Wade D, Cotton S, Gee D, Pearce T, Crisp K, McGorry PD, Gleeson JF (2008). Enhancing treatment fidelity in psychotherapy research: novel approach to measure the components of cognitive behavioural therapy for relapse prevention in first-episode psychosis. Australian New Zealand Journal of Psychiatry 42, 1013-1020.
Bebbington P (2009). Childhood sexual abuse and psychosis: aetiology and mechanism. Epidemiology and Social Psychiatry 18, 284-293.

Cohen DJ, Crabtree BF, Etz RS, Balasubramanian BA, Donahue KE, Leviton LC, Clark EC, Isaacson NF, Stange KC, Green LW (2008). Fidelity versus flexibility: translating evidence-based research into practice. American Journal of Preventive Medicine 35, S381-S389.

Jackson C, Trower P, Reid I, Smith J, Hall M, Townend M, Barton K, Jones J, Ross K, Russell R, Newton E, Dunn G, Birchwood M (2009). Improving psychological adjustment following a first episode of psychosis: a randomised controlled trial of cognitive therapy to reduce post psychotic trauma symptoms. Behavioural Research and Therapy 47, 454-462.

Kidd SA, George L, O'Connell M, Sylvestre J, Kirkpatrick H, Browne G, Thabane L (2010). Fidelity and recovery-orientation in assertive community treatment. Community Mental Health Journal 46, 342-350.

Lasalvia A, Tansella M (2009). Childhood trauma and psychotic disorders: evidence, theoretical perspectives, and implication for interventions. Epidemiology and Social Psychiatry 18, 277-283.

McHugo GJ, Drake RE, Whitley R, Bond GR, Campbell K, Rapp CA, Goldman HH, Lutz WJ, Finnerty MT (2007). Fidelity outcomes in the National Implementing Evidence-Based Practices Project. Psychiatric Services 58, 1279-1284.

Morrison AP, Barratt S (2010). What are the components of CBT for psychosis? A Delphi study. Schizophrenia Bulletin 36, 136-142.

Onwumere J, Kuipers E, Bebbington P, Dunn G, Freeman D, Fowler D, Garety P (2010). The need for closure in caregivers of people with psychosis. Epidemiology and Social Psychiatry 19, 159-167.

Petrakis M, Hamilton B, Penno S, Selvendra A, Laxton S, Doidge G, Svenson M, Castle D (2010). Fidelity to clinical guidelines using a care pathway in the treatment of first episode psychosis. Journal of Evaluation and Clinical Practice 10 (epub ahead of print) 